\title{
Temporal variation in elytral colour polymorphism in Hippodamia variegata (Coleoptera: Coccinellidae)
}

\author{
Alois HONEK ${ }^{1}$, Zdenka MARTINKOVA ${ }^{1}$, PAVEl SASKA $^{1}$ and ANTHony F.G. DIXON ${ }^{2}$ \\ 'Crop Research Institute, Drnovska 507, 16106 Praha 6 - Ruzyne, Czech Republic, e-mails: honek@vurv.cz; martinkova@vurv.cz; \\ saska@vurv.cz \\ ${ }^{2}$ University of East Anglia, School of Biological Sciences, Norwich NR4 7TJ, United Kingdom, e-mail: a.f.dixon@uea.ac.uk
}

\begin{abstract}
Key words. Coccinellidae, Hippodamia variegata, Adonia, lady beetle, polymorphism, elytra, thermoregulation, climate
\end{abstract}
\begin{abstract}
Lady beetles (Coleoptera: Coccinellidae) are a classical group for studying the mechanisms that determine local and temporal trends in colour polymorphism. Here we report long term trends in variation in the percentage of different morphs in a population of Hippodamia variegata (Goeze) at Štúrovo, Slovakia $\left(47^{\circ} 48^{\prime} \mathrm{N}, 18^{\circ} 43^{\prime} \mathrm{E}\right)$. The morphs differ in the number and location of the spots on their elytra. Beetles were sampled from stands of herbaceous plants using a standard method each year in August over a period of 74 years from 1937 to 2011. Twenty two morphs (out of 74 possible) were recorded in a total sample of 6,984 individuals. Four dominant morphs made up $90 \%$ of the total sample and varied in their annual frequency independently of one another. Frequency of "pale" morphs (0-3 spots per elytra), supposedly favoured by a warm climate, increased from 1981 to 2000 s' during a period of climate warming, but only after a decrease that took place between 1937 and 1981, which did not parallel a change in climate. Moreover, the differences in the extent of the melanization of the elytral surface are too small to significantly affect thermoregulation in the different morphs. Therefore, the results presented do not provide unequivocal support for climate change determining the long term trends in the variation in the proportions of the different morphs.
\end{abstract}

\section{INTRODUCTION}

Morphological polymorphisms are well studied and provide evidence of natural variation and microevolutionary processes occurring in nature (Ford, 1964). Although these studies now seems "marginal" compared to the flood of information from molecular studies (Lowe et al., 2004) they are important because they provide direct evidence of interaction between environmental factors and animal characteristics at the organismic level. Among the frequently studied polymorphic taxa lady beetles (Coleoptera: Coccinellidae) occupy a prominent position, in particular the results of studies on the polymorphism in the pattern and colour of their dorsal surface: head (Rogers et al., 1971), scutum (Blehman, 2007) and elytra. The pattern on the elytra varies in terms of the base colour and number, size and shape of spots. The few species that are the classical subjects of these studies have a small number of morphs in which the base colour of the elytra differs and is determined by major genes. There are many studies on local and temporal variation in proportions of morphs in populations (Sloggett \& Honek, 2012). In most cases the occurrence of morphs appears to be associated with climatic factors, industrial pollution (Zakharov, 2003) and, possibly, visual predation (Brakefield, 1985). It is supposed that "melanic" morphs have an advantage over "pale" nonmelanic morphs in cold and/or humid areas. Dark coloured individuals are able to quickly increase their body temperature when sunlight penetrates overcast skies and the resultant greater activity results in an increase in breeding success (Brakefield \& Willmer, 1985; de Jong et al., 1996). However, mechanisms balancing the ratio of particular morphs in populations are still open to dispute and worthy of further study (Majerus, 1994).

Of particular interest is the maintenance of polymorphism in species that do not show conspicuous variation in the base colour of their elytra, which is supposed to be important for the operation of selection in these species. An example is Hippodamia (= Adonia) variegata (Goeze), a species in which the morphs differ only in the number, size and merging of the spots. This Palaearctic species is found also in central Africa and India (Bielawski, 1959) and was introduced into North (Schaefer \& Dysart, 1988) and South America (Grez et al., 2004). In central Europe this species colonizes stands of wild herbaceous plants and crops infested with a variety of aphid species (Honek, 1985; Nedved, 1999). As this species has 2-3 generations per year, all of which may overwinter, this species is abundant in late summer. There is a very rich variety of morphs in this species, which differ in the pattern of spots on their elytra. The proportion of the different morphs in local populations varies geographically. In the Western Palearctic the dominant morphs lack confluent spots but in the Eastern Palearctic the dominant morphs are "melanic" with confluent spots. It has been concluded that the proportion of "melanic" morphs in an area increases with the level of humidity recorded there (Dobzhansky, 1933). At localities in Central Europe the proportions of the different morphs in local populations are similar (Schilder, 1952). The population of this species at Štúrovo, southern Slovakia, provides an excellent opportunity to study the temporal changes in the percentages of the various morphs as it has been sampled repeat- 
edly since the 1930's, by Strouhal (1939), BalthasarovaHrubantova (1951) and the present authors. To explain this temporal variation, we proposed the hypothesis that the variation in occurrence of beetles with larger or smaller numbers of spots is correlated with climatic changes and tested for a trend in the percentage of particular morphs, with an increase in pale morphs with increase in ambient temperature expected.

\section{MATERIAL AND METHODS}

\section{Species studied}

The colour pattern on the scutum and elytra of $H$. variegata is very variable (Strouhal, 1939). The pattern on the elytra, which is the topic addressed in this study, is that of the spots located at 6 specific positions (Fig. 1). Any of these spots may be either present or absent, regardless of the state of the other spots. Thus, the pattern on each elytron may consist of 0 to 6 spots in one of 74 combinations of which 22 were recorded in this study (Fig. 1). The seventh spot, which is in the centre of the scutellum and present in all individuals, was not included in this study. Rare individuals $(0.14 \%$ of the total sample) in which pairs of spots merge were classified as if the spots had not merged. In addition, the morphs were also arbitrarily classified as "pale" if there were $0-3$ spots and "melanic" if there were 4-6 spots on each elytron.

\section{Sampling}

The beetles were sampled within $20 \mathrm{~km}$ of Štúrovo, Slovakia $\left(47^{\circ} 48^{\prime} \mathrm{N}, 18^{\circ} 43^{\prime} \mathrm{E}, 110 \mathrm{~m}\right.$ a.s.l.). The terrain in this area is flat and consists of intensely cultivated large fields bordered by woody hedgerows and interspersed with small vineyards, uncultivated steppe and broadleaved forests. Typical crops are cereals, maize, alfalfa and sugar beet. Since 1971, samples of $H$. variegata were collected by the senior author $(\mathrm{AH})$, each year between $10^{\text {th }}$ to $30^{\text {th }}$ of August. They were sampled from stands of alfalfa and wild herbaceous plants (particularly umbellifers), using an entomological sweep net, on warm still days between 08:00-18:00 h, when adults are active in the upper stratum of vegetation. The beetles sampled were put in alcohol and later sorted in the laboratory based on their elytral pattern. Beetles collected after 2004 were preserved in alcohol. Data for 1937 (Strouhal, 1939) and 1950 (Balthasarova-Hrubantova, 1951) were retrieved from literature. The period of time covered by the data is thus 74 years.

\section{Data processing}

The beetles were each assigned to one of 7 categories, each defined by the number of spots present on the elytra ( 0 to 6 spots) regardless of their position and to 22 morphs each characterized by a specific number and position of the spots on the elytra (Fig. 1). The frequencies of particular morphs differed in each of the 14 years sampled. Data for 2003 and 2006 were excluded from further analysis because of small sample size. Differences in morph frequencies between other years (sample size $154-2,296$ individuals) were tested using GL saturated model with Poisson error structure and log link function, using individual counts as a response variable and morph, year and their interaction as explanatory terms. Then particular years were grouped based on the percentages of the different morphs using cluster analysis with Euclidean distances and complete linkage, in order to remove the influence of the variation in annual sample size. Percentage frequencies of the abundant morphs (making up $>5$ percent of total catch) were further tested using a z-test (Systat Software, 2006). Percentage of a
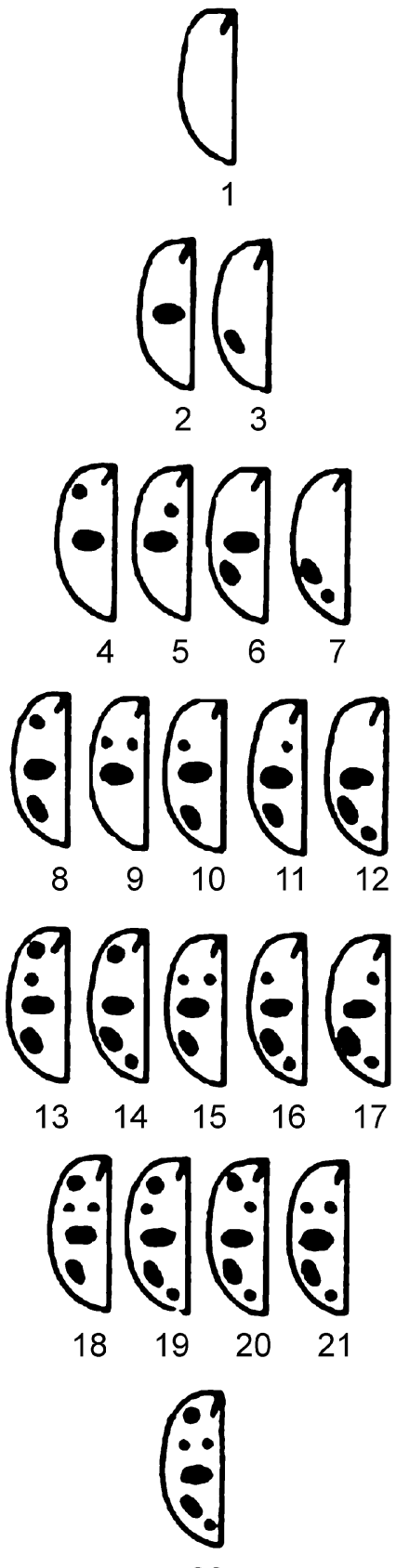

22

Fig. 1. Elytral colour patterns recorded during the course of this study. Numbering of the morphs throughout the text corresponds to that used in this Figure. The rows represent categories with particular numbers of spots, starting from 0 (top) to 6 (bottom).

morph in the total sample for a particular year was tested against percentage of the same morph in each of the other years.

The relationship between temperature in spring and summer and the percentage of the different morphs was investigated using data for 1992-2011. Percentages of individuals belonging to each of the categories characterised by a particular number of spots were separately regressed on average temperatures over periods (April-July, April-August, May-July and May-August) that might have affected individuals collected in late August in each of these years. This data was calculated using monthly mean temperatures (whole day temperatures calculated using standard method and data collected at 07:00 h, 14:00 h and 


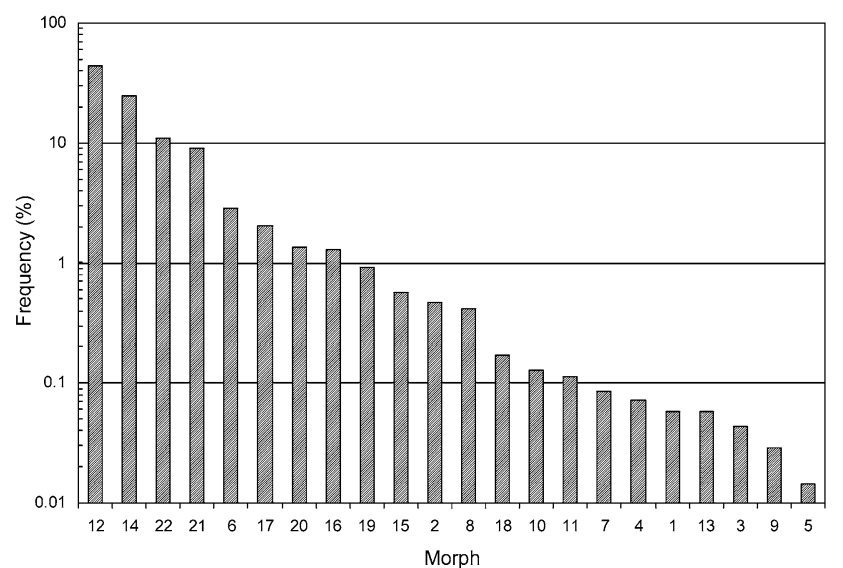

Fig. 2. Frequency of particular morphs in the total sample collected over the period 1937-2011. The morphs are indicated by the numbers used in Fig. 1.

21:00 h) at Bratislava (located c. $130 \mathrm{~km}$ from the sites sampled, http://www.weatheronline.cz). Long term records of the changes in temperature in Central Europe were obtained from Prague Klementinum, where the record goes back to 1775 (http:// zmeny-klima.ic.cz/).

To estimate the percentage of the surface area of the elytra covered by black spots their areas were measured using an optical planimeter and photographs of individuals with spots of different sizes.

\section{RESULTS}

A total of 6,984 individuals belonging to 22 colour morphs were collected over the 74 year period from 1937 to 2011 (Appendix), which is only a fraction (30\%) of the total of 74 possible morphs. Four morphs 12 (3-spot), 14 (4-spot), 21 (5-spot), 22 (6-spot) (Fig. 2), each making up $>5 \%$ of the total sample, were sampled every year and together made up $89.3 \%$ of the total sample. Four less abundant morphs, 6, 16, 17 and 20, each making up $1-5 \%$ of the total sample occurred regularly each year except 1981 (missing morph 16), 1992 and 2005 (missing morph 6), and 2010 (missing morph 20). Of the total sample they made up $7.5 \%$. There were also fourteen rare morphs that each made up less than $1 \%$ of the total sample and together $3.2 \%$.

The frequency of individuals with particular numbers of spots varied between years (GLM-p, deletion test: $\chi^{2}{ }_{231}$ $=703.65, \mathrm{p}<<0.001)$. The percentage of "pale" morphs with $0-3$ spots was high in 1937, then decreased to a minimum in 1981 and again increased up to 2006-2011 (Fig. 3). Particular years were grouped in two main clusters (Fig. 4), one consisting of 1981, 1992 and 2005, years in which there were low percentages of the 3-spot morph 12, and high percentages of 5-spot (21) and 6-spot (22) morphs. The other cluster included the remaining years with different combinations of morphs. This cluster includes three sub-lineages one of which includes 1937 and 2007-2010, which indicates that the morph composition of the $H$. variegata population at the end of the monitoring period was similar to that at the beginning. The percentage of particular abundant morphs varied independently of one another and the patterns of similarity in
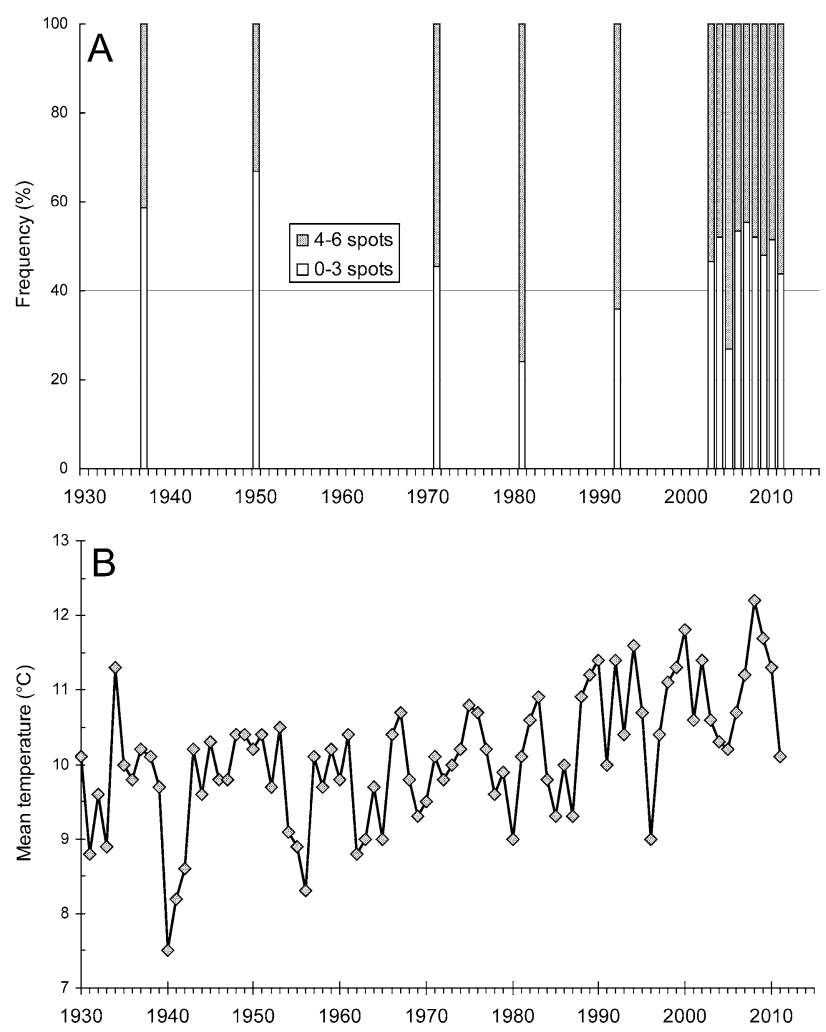

Fig. 3. A - Percentage of beetles with 0-3 spots ("pale" morphs) and 4-6 spots ("melanic" morphs) on their elytra in particular years. B - Mean annual temperatures in particular years. Data from the meteorological station of Prague Klementinum.

percentage between particular years were specific for each morph (Fig. 5).

The percentages of the abundant morphs in 1992-2011 were not significantly related to weather prevailing in the season when the beetles developed. The regression of the percentage of particular abundant morphs, 12 (3-spot), 14 (4-spot), 21 (5-spot) and 22 (6-spot), or of 3-spot plus 4 -spot morphs $(12+14)$ or 5-spot plus 6-spot morphs $(21$ +22 ) on any combination of April to August mean tem-

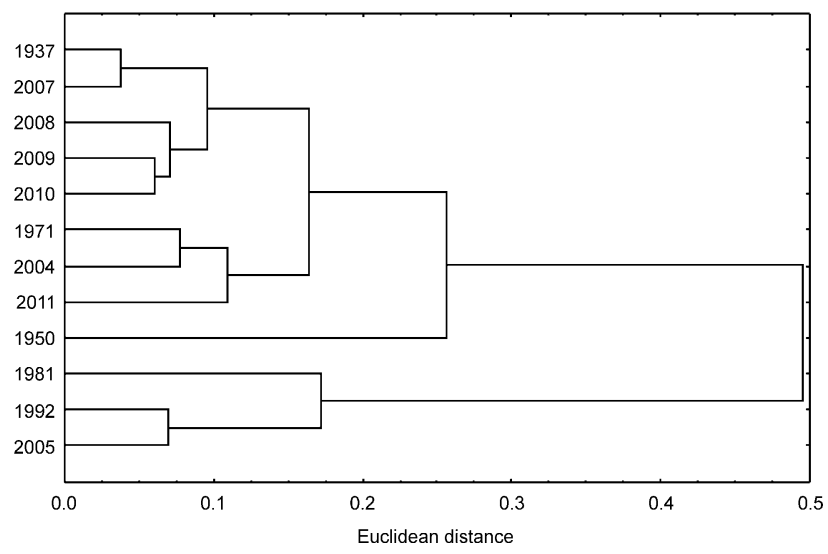

Fig. 4. Results for the years sampled grouped according to the frequency of individuals with different numbers of spots in the total sample using cluster analysis (complete linkage, Euclidean distance). 

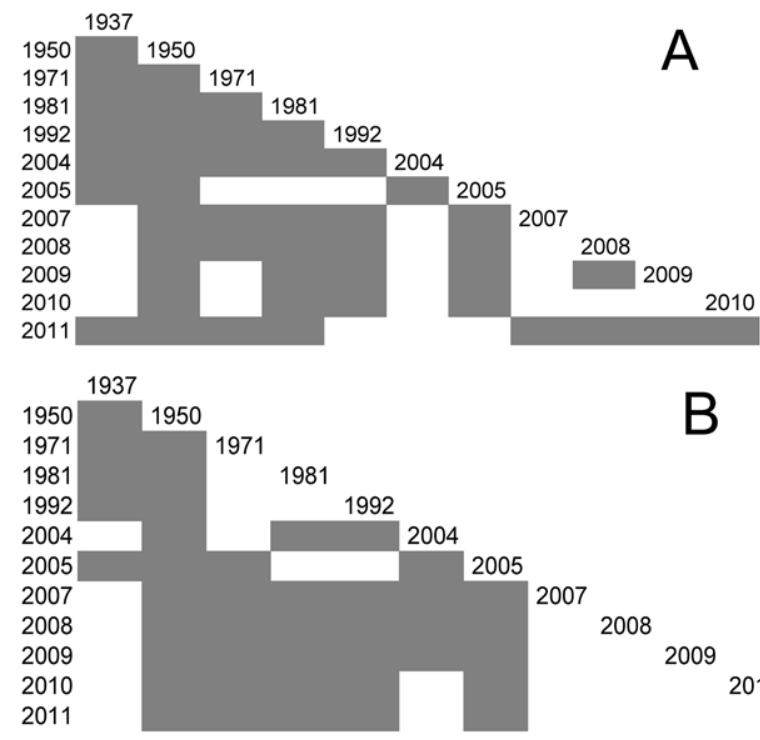

B

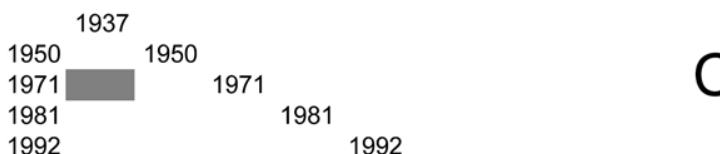

20042004

2005

2007

2009

2010

2011

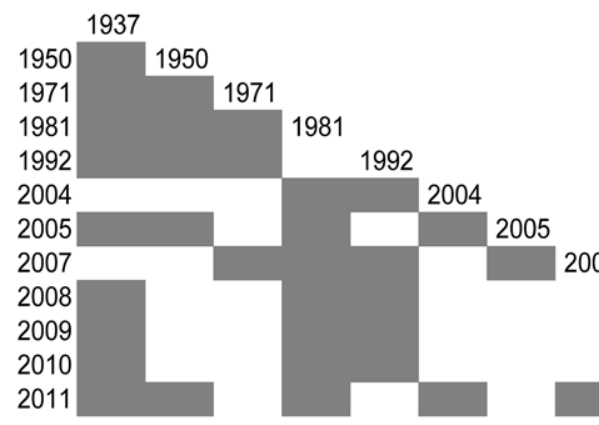

2007

2008

2009

Fig. 5. Significant differences between particular years $(\mathrm{P}<$ 0.05 , z-test of percentages, shaded) in percentages of abundant morphs (numbering as in Fig. 1). A - 3-spot morph 12; B 4-spot morph 14; C - 5-spot morph 21; D - 6-spot morph 22.

perature were not significant $(\mathrm{P}=0.171-0.540)$. In fact, the morphs were similar in the percentage of the surface of their elytra covered by black spots, which was $9 \%$ (when the spots were small) - 15\% (spots large) in 3-spot morph $12,10-19 \%$ in 4 -spot morph $14,11-19 \%$ in 5 -spot morph 21 and $12-22 \%$ in 6-spot morph 22 .

\section{DISCUSSION}

First, we should address a problem associated with this type of study, which is the absence of a genetic analysis of spot pattern polymorphism in $H$. variegata (Majerus, 1994). In coccinellids where the morphs differ fundamentally in pattern and base coloration of the elytra, the inheritance the pattern is via multiple alleles of a major gene. This is the case in Adalia bipunctata (L.) (Schröder,
1909; Fiori, 1928; Lusis, 1928), Harmonia axyridis (Pallas) (Tan \& Li, 1934; Hosino, 1936) and Olla v-nigrum (Mulsant) (Vandenberg, 1992) in which melanic morphs are dominant and in Coelophora species (Chazeau, 1980; Houston \& Hales, 1980) in which the pale morph is dominant. Hippodamia variegata only varies in the pattern of the distribution of the spots on the elytra. Of 74 possible spot combinations only $22(30 \%)$ were present in the natural populations studied, which indicates there may be a genetic constraint on the extent of the variation. In other coccinellid species similar variation, although under genetic control (Lusis, 1932; Zarapkin, 1938; Hosino, 1942), is modified by the temperature experienced by an insect at certain sensitive stages in its development (Zimmermann, 1931; Okuda et al., 1997; Michie et al., 2010). With increasing temperature the size of spots decreases gradually until some spots do not develop at high temperatures. In $H$. variegata the variation in the size of spots is constrained with the lower limit to their size usually far from zero. The assumed reduction in size of spots caused by experiencing high temperatures during development probably rarely ends in spot elimination. The pattern of spots is likely to be determined genetically but this needs to be verified.

The results provide an opportunity to discuss the temporal variation in the percentage of individuals with different elytral patterns in $H$. variegata. As the data contradicted the hypothesis of stable morph composition we first looked for variation consistent with change in climatic factors already demonstrated in other coccinellid species. The composition of morphs in populations of $A$. bipunctata in xeric Central Europe has remained stable for 33 years (Honek et al., 2005) while in populations in areas with a humid oceanic climate it has changed. It is suggested that these changes are determined by the level of industrial air pollution (Creed, 1971; Zakharov, 2003) and changes in climate (de Jong \& Brakefield, 1998; Brakefield \& de Jong, 2011). Directional long-term changes also occur in local populations of $H$. axyridis (Komai \& Chino, 1969). In both these species the temporal variation in the frequency of morphs involves changes in the percentages of "pale" (yellow or red background colour with black spots) and "melanic" (black with yellow or red spots) morphs. In contrast, in $H$. variegata there are several morphs only arbitrarily divided into "pale" and "melanic" forms. If we assume that "melanic" morphs (4-6 spots) are at an advantage when the weather is cold and overcast and the "pale" morphs (0-3 spots) when the weather is warm, then the long term variation in percentages of different morphs should parallel climate trends, but the results indicate they only partly parallel these trends (Fig. 3). The temperatures remained low between 1930 and 1980 then gradually increased up to the end of the period studied (Anonymous, 2010). During the latter period the highest increase in temperature was for April-August and decrease in rainfall for April-June, which was accompanied by an increase in the number of hours of sunshine (Anonymous, 2010). In fact changes in percentages of the different morphs of $H$. variegata fitted 
the prediction after 1980 when the percentage of "pale" morphs increased in parallel with the warming in the weather. However, the decrease in the percentage of "pale" morphs between 1937 and 1981 is not paralleled by a cooling in the climate. Another reservation, when seeking an explanation for changes in the percentage composition of the different morphs in terms of climatic change, is the existence of short term oscillations in morph composition (2005), which might bias the estimation of long term trends when using incomplete data.

Studies on species with morphs that differ in the base colour of their elytra and pattern of spots reveal the crucial role of thermoregulation in balancing morph proportions (Sloggett \& Honek, 2012). They lead to local differences in the proportions of the different morphs (Komai \& Hosino, 1951; Bengtson \& Hagen, 1975) and can change relatively fast when the climate changes (Brakefield \& Lees, 1987; de Jong \& Brakefield, 1998; Majerus \& Zakharov, 2000; Brakefield \& de Jong, 2011). It is unlikely that thermoregulation has affected the percentages of the different morphs in the Sturovo population of $H$. variegata. The differences in the median percentages of the surface area of the elytra covered with melanic spots in the most abundant morphs are small and overlapping. Therefore the variation in percentage of elytral surface that is melanic is unlikely to result in significant differences in the body temperatures of the different morphs.

Temporal changes are important when evaluating local variation in the percentages of different morphs. The composition of the population at Sturovo is generally similar to that of populations at other localities in Central (Schilder, 1928, 1952; Schilder \& Schilder, 1951) and Eastern Europe (Dobzhansky, 1933). The occurrence of particular morphs is nearly identical [one morph lacking confluent spots in Schilder's (1952) list was not present in our samples] and the order of abundant morphs is similar. The major difference is in the variation in the percentages of the rarer morphs. As there is a significant temporal variation in morph composition of local populations, geographic comparisons based on data collected in different years are confounded by temporal variation in percentages of the different morphs.

Causes of the significant long term variation in percentages of the different morphs of $H$. variegata thus remain to be determined. As in other species further progress requires an experimental study of the genetic basis of colour polymorphism and the reaction norms of the various morphs to temperature. This supplementary information will make this species a likely subject for studies on ecological genetics.

ACKNOWLEDGEMENTS. The work was supported by grant no. 522/08/1300 of the Grant Agency of Czech Republic.

\section{REFERENCES}

AnONYmous 2010: Information panel on climatic change. Meteor. Bull. 63: 5-8.
Balthasarova-Hrubantova E. 1951: Contribution à la connaissance de la variabilité de l'espèce Adonia variegata Goeze. Prirodovedny Sbornik (Bratislava) 5: 193-206.

Bengtson S.A. \& Hagen R. 1975: Polymorphism in the twospot ladybird Adalia bipunctata in western Norway. Oikos 26: 328-331.

BIELAWSKI R. 1959: Biedronki - Coccinellidae. Panstwowe Wydawnictwo Naukowe, Warszawa, 92 pp.

Blehman A.V. 2007: Variability of pronotum patterns in ladybird beetle Harmonia axyridis Pallas (Coleoptera, Coccinellidae). Ekol. Genet. 5: 25-36.

BRAKEFIELD P.M. 1985: Polymorphic Müllerian mimicry and interactions with thermal melanism in ladybirds and a soldier beetle: a hypothesis. Biol. J. Linn. Soc. 26: 243-265.

BRaKefIELd P.M. \& DE Jong P.W. 2011: A steep cline in ladybird melanism has decayed over 25 years: a genetic response to climate change? Heredity 107: 574-578.

Brakefield P.M. \& Lees D.R. 1987: Melanism in Adalia ladybirds and declining air pollution in Birmingham. Heredity 59: 273-277.

BRAKeField P.M \& Willmer P.G. 1985: The basis of thermal melanism in the ladybird Adalia bipunctata: Differences in reflectance and thermal properties between the morphs. Heredity 54: 9-14.

Chazeau J. 1980: On polymorphism in elytral coloration pattern in Coelophora quadrivittata (Coleoptera, Coccinellidae). Entomol. Exp. Appl. 27: 194-198.

CREed E.R. 1971: Industrial melanism in the two-spot ladybird and smoke abatement. Evolution 25: 290-293.

DE Jong P.W. \& Brakefield P.M. 1998: Climate and change in clines for melanism in the two-spot ladybird, Adalia bipunctata (Coleoptera: Coccinellidae). Proc. R. Soc. Lond. (B) 265 : 39-43.

De Jong P.W., Gussekloo S.W.S. \& Brakefield P.M. 1996: Differences in thermal balance, body temperature and activity between non-melanic and melanic two-spot ladybird beetles (Adalia bipunctata) under controlled conditions. J. Exp. Biol. 199: 2655-2666.

DoBZHANSKY T. 1933: Geographical variation in lady-beetles. Am. Nat. 67: 97-126.

FIORI A. 1928: Ricerche sul comportamento ereditario di alcune varieta di Adalia bipunctata. Boll. Lab. Zool. Portici 22: 285-304.

Ford E.B. 1964: Ecological Genetics. Methuen, London, 335 pp.

Grez A., Zaviezo T., Tischendorf L. \& Fahrig L. 2004: A transient, positive effect of habitat fragmentation on insect population densities. Oecologia 141: 444-451.

HoneK A. 1985: Habitat preferences of aphidophagous coccinellids (Coleoptera). Entomophaga 30: 253-264.

Honek A., Martinkova Z. \& Pekar S. 2005: Temporal stability of morph frequency in central European populations of Adalia bipunctata and A. decempunctata (Coleoptera: Coccinellidae). Eur. J. Entomol. 102: 437-442.

Hosino Y. 1936: Genetical studies of the lady-bird beetle, Harmonia axyridis Pallas (Report II). Jap. J. Genet. 12: 307-320.

Hosino Y. 1942: Genetical studies of the lady-bird beetle, Harmonia axyridis Pallas (Report VI). Jap. J. Genet. 18: 285-296.

Houston K.J. \& Hales D.F. 1980: Allelic frequencies and inheritance of colour pattern in Coelophora inaequalis (F.) (Coleoptera: Coccinellidae). Aust. J. Zool. 28: 669-677.

Komai T. \& Chino M. 1969: Observations on geographic and temporal variations in the ladybeetle Harmonia. I. Proc. Jap. Acad. 45: 284-288. 
Komai T. \& Hosino Y. 1951: Contributions to the evolutionary genetics of the lady-beetle, Harmonia. II. Microgeographic variations. Genetics 36: 382-390.

Lowe A., Harris S. \& Ashton P. 2004: Ecological Genetics: Design, Analysis and Application. Blackwell, Malden, 326 pp.

LUSIS YA.YA. 1928: On the inheritance of colour and pattern in the lady-beetles Adalia bipunctata and A. decempunctata. Bull. Bureau Genet. Acad. Sci. USSR 6: 89-163.

Lusis YA.YA. 1932: An analysis of the dominance phenomenon in the inheritance of the elytra and pronotum colour in Adalia bipunctata. 1. Trudy Lab. Genetiki 9: 135-162.

MaJERus M.E.N. 1994: Ladybirds. Harper Collins, London, 367 pp.

MAJERUS M.E.N. \& ZAKHAROV I.A. 2000: Does thermal melanism maintain melanic polymorphism in the two-spot ladybird, Adalia bipunctata (Coleoptera: Coccinellidae)? $\mathrm{Zh}$. Obshch. Biol. 61: 381-392.

Michie L.J., Mallard F., Majerus M.E.N. \& Jiggins F.M. 2010 Melanic through nature or nurture: genetic polymorphism and phenotypic plasticity in Harmonia axyridis. J. Evol. Biol. 23: $1699-1707$.

Nedved O. 1999: Host complexes of predaceous ladybeetles (Col., Coccinellidae). J. Appl. Entomol. 123: 73-76.

OKudA T., Gomi T. \& HodeK I. 1997: Effect of temperature on pupal pigmentation and size of the elytral spots in Coccinella septempunctata (Coleoptera: Coccinellidae) from four latitudes in Japan. Appl. Entomol. Zool. 32: 567-572.

Rogers C.E., Jackson H.B., Eikenbary R.D. \& Starks K.J. 1971: Sex determination in Propylea 14-punctata (Coleoptera: Coccinellidae), an important predator of aphids. Ann. Entomol. Soc. Am. 64: 957-959.

Schaefer P.W. \& Dysart R.J. 1988: Palearctic aphidophagous coccinellids in North America. In Niemczyk E. \& Dixon A.F.G. (eds): Ecology and Effectiveness of Aphidophaga. SPB Academic Publishing, The Hague, pp. 99-103.
SCHILDER F.A. 1928: Zur Variabilität von Adonia variegata Goeze (Col. Coccinell.). Entomol. Blätter 24: 129-142.

SCHILDER F.A. 1952: Neue Variationsstudien an Coccinelliden. Wiss. Z. Martin-Luther-Univ. Halle-Wittenberg 2: 143-163.

SCHILDER F.A. \& SCHILDER M. 1951: Methoden der Phänoanalyse von Tieren. Wiss. Z. Martin-Luther-Univ. HalleWittenberg 1: 81-91.

SCHRÖDER C. 1909: Die Erscheinungen der Zeichnungsvererbung bei Adalia bipunctata L. und ihren ab. 6-pustulata L. und 4-maculata Scop. Z. Wiss. Insektenbiol. 5: 132-134.

Sloggett J.J. \& HoneK A. 2012: Genetic studies. In Hodek I., van Emden H. \& Honek A. (eds): Ecology and Behaviour of the Ladybird Beetles. Wiley-Blackwell, Oxford, pp. 13-53.

Strounal H. 1939: Variationsstatistische Untersuchung an Adonia variegata Gze (Col. Coccinell,). Z. Morph. Ökol. Tiere 35: 288-316.

Systat Software 2006: Sigma Stat 3.5 for Windows. Systat Software, Point Richmond, 844 pp.

TAN C.C. \& Li J.C. 1934: Inheritance of the elytral color patterns of the lady-bird beetle, Harmonia axyridis Pallas. Am. Nat. 68: 252-265.

VANDENBERG N.J. 1992: Revision of the New World lady beetles of the genus Olla and description of a new allied genus (Coleoptera, Coccinellidae). Ann. Entomol. Soc. Am. 85: 370-392.

ZAKHAROV I.A. 2003: Industrial melanism and its dynamics in populations of the two-spot ladybird Adalia bipunctata L. Usp. Sovr. Biol. 123: 3-15.

ZARAPKIN S.R. 1938: Über die gerichtete Variabilität der Coccinelliden. V. Die Reihenfolge der Fleckenentstehung auf den Elytren der Coccinella 10-punctata (Adalia 10-punctata) in der ontogenetischen Entwicklung. Z. Morph. Ökol. Tiere 34: 565-572.

Zimmermann K. 1931: Wirkung von Selektion und Temperatur auf die Pigmentierung von Epilachna chrysomelina F. Naturwissenschaften 19: 768-781.

Received December 28, 2011; revised and accepted March 7, 2012

APPENDIX 1. Numbers of individuals of morphs 1-22 (Fig. 1) in samples collected in years 1937-2011.

\begin{tabular}{cccccccccccccccc}
\hline Morph & 1937 & 1950 & 1971 & 1981 & 1992 & 2003 & 2004 & 2005 & 2006 & 2007 & 2008 & 2009 & 2010 & 2011 & Total \\
\hline 1 & 0 & 1 & 1 & 0 & 0 & 0 & 0 & 0 & 0 & 0 & 0 & 0 & 0 & 2 & 4 \\
2 & 3 & 4 & 11 & 1 & 1 & 2 & 0 & 2 & 0 & 1 & 3 & 3 & 1 & 1 & 33 \\
3 & 0 & 2 & 1 & 0 & 0 & 0 & 0 & 0 & 0 & 0 & 0 & 0 & 0 & 0 & 3 \\
4 & 2 & 1 & 0 & 1 & 0 & 0 & 0 & 1 & 0 & 0 & 0 & 0 & 0 & 0 & 5 \\
5 & 0 & 0 & 0 & 1 & 0 & 0 & 0 & 0 & 0 & 0 & 0 & 0 & 0 & 0 & 1 \\
6 & 25 & 45 & 62 & 2 & 0 & 0 & 9 & 5 & 0 & 11 & 10 & 11 & 8 & 12 & 200 \\
7 & 1 & 0 & 2 & 0 & 0 & 0 & 1 & 0 & 0 & 0 & 0 & 2 & 0 & 0 & 6 \\
8 & 8 & 1 & 9 & 0 & 0 & 0 & 1 & 0 & 0 & 1 & 2 & 2 & 0 & 5 & 29 \\
9 & 0 & 1 & 1 & 0 & 0 & 0 & 0 & 0 & 0 & 0 & 0 & 0 & 0 & 0 & 2 \\
10 & 1 & 1 & 1 & 0 & 0 & 0 & 3 & 0 & 0 & 0 & 0 & 1 & 0 & 2 & 9 \\
11 & 1 & 2 & 1 & 0 & 0 & 0 & 1 & 0 & 0 & 1 & 0 & 1 & 0 & 1 & 8 \\
12 & 255 & 461 & 957 & 32 & 112 & 18 & 114 & 114 & 8 & 138 & 288 & 310 & 123 & 189 & 3119 \\
13 & 0 & 0 & 1 & 0 & 0 & 0 & 0 & 2 & 0 & 0 & 0 & 0 & 1 & 0 & 4 \\
14 & 98 & 97 & 699 & 59 & 108 & 11 & 64 & 136 & 2 & 50 & 102 & 133 & 57 & 112 & 1728 \\
15 & 4 & 9 & 8 & 0 & 0 & 0 & 1 & 2 & 0 & 3 & 2 & 1 & 1 & 9 & 40 \\
16 & 13 & 6 & 28 & 0 & 5 & 1 & 2 & 2 & 1 & 13 & 3 & 7 & 2 & 6 & 89 \\
17 & 9 & 8 & 40 & 4 & 6 & 0 & 6 & 4 & 2 & 7 & 19 & 26 & 2 & 9 & 142 \\
18 & 0 & 0 & 6 & 1 & 0 & 0 & 0 & 0 & 0 & 0 & 2 & 2 & 0 & 1 & 12 \\
19 & 1 & 5 & 24 & 5 & 2 & 1 & 3 & 7 & 0 & 0 & 1 & 14 & 0 & 1 & 64 \\
20 & 5 & 3 & 24 & 2 & 6 & 0 & 5 & 11 & 0 & 5 & 10 & 12 & 0 & 11 & 94 \\
21 & 53 & 66 & 164 & 9 & 20 & 3 & 20 & 32 & 0 & 26 & 59 & 89 & 34 & 55 & 630 \\
22 & 25 & 63 & 256 & 37 & 54 & 7 & 18 & 54 & 2 & 18 & 60 & 73 & 27 & 68 & 762 \\
\hline Total & 504 & 776 & 2296 & 154 & 314 & 43 & 248 & 372 & 15 & 274 & 561 & 687 & 256 & 484 & 6984 \\
\hline & & & & & & & & & & & & & & \\
\hline
\end{tabular}

